\title{
Physicochemical properties and enzymatic bean grains dried at different temperatures and stored for 225 days
}

\section{Propriedades físico-químicas e enzimática de grãos de feijão secos em diferentes temperaturas e armazenados por 225 dias}

\author{
Moacir Cardoso Elias ${ }^{1}$; Valmor Ziegler ${ }^{2 *}$; Catia Maria Romano ${ }^{2}$; \\ Gabriela Hornke Alves²; Ricardo Tadeu Paraginski²; Maurício de Oliveira ${ }^{1}$
}

\begin{abstract}
Beans are an important food in the world and are present on the tables of Brazilians almost daily. The harvest of these grains occurs seasonally during the year, and hence, steps after harvesting are essential to maintain product demand. However, the drying and storage conditions may alter the characteristics of the beans, reducing their economic value and their acceptability to consumers. The objective of this study was to evaluate the impact of storage time on the chemical, technological and enzymatic parameters of black beans dried at three temperatures $\left(30,45\right.$ and $\left.60{ }^{\circ} \mathrm{C}\right)$ and stored for 225 days in conventional woven polypropylene bags. The results show that the increase in storage time leads to a lower protein solubility, and a decreased content of tannins, lipids and proteins; and an increased cooking time, fat acidity, and the enzymatic activity of peroxidase and polyphenol oxidase. These parameters are important in the quality control of beans for consumption and as a raw material for the food industry. The quantity of broken grains and the grain roughness index are only influenced by the drying temperature regardless of the storage time of 225 days.
\end{abstract}

Key words: Conservation. Quality. Phaseolus vulgaris L. Postharvest.

\section{Resumo}

O feijão é um alimento importante em todo o mundo, estando presente quase que diariamente na mesa dos brasileiros. A colheita desses grãos ocorre sazonalmente durante o ano, e por isso, as etapas de póscolheita são imprescindíveis para manter a demanda do produto, no entanto, as condições de secagem e armazenamento podem alteram suas características, reduzindo o valor econômico e a aceitabilidade dos consumidores. O objetivo do estudo foi avaliar os efeitos do tempo de armazenamento sobre parâmetros químicos, tecnológicos e enzimáticos de avaliação da qualidade de grãos de feijão preto secos em três temperaturas $\left(30,45\right.$ e $\left.60^{\circ} \mathrm{C}\right)$, e armazenados por 225 dias em um sistema convencional de sacos de polipropileno trançado. Os resultados mostram que o aumento do tempo de armazenamento provoca redução da solubilidade proteica, dos níveis de taninos, do conteúdo de lipídios e de proteínas, com o aumento do tempo de cocção, da acidez lipídica e da atividade enzimática da peroxidase e polifenoloxidase à 30,45 e $60^{\circ} \mathrm{C}$. Esses parâmetros são importantes para o controle de qualidade dos grãos para o consumo e como matéria-prima para a indústria de alimentos. A quantidade de grãos quebrados e o índice de rugosidade dos grãos são alterados apenas pela temperatura de secagem, independentemente do tempo de armazenamento de 225 dias.

Palavras-chave: Conservação. Qualidade. Phaseolus vulgaris L. Pós-colheita.

${ }^{1}$ Profs. Drs., Programa de Pós-Graduação em Ciência e Tecnologia de Alimentos, Universidade Federal de Pelotas, DCTA/FAEM/ UFPEL, Pelotas, RS, Brasil. E-mail: eliasmc@uol.com.br; mauricio@labgraos.com.br

2 Discentes do curso de Doutorado, Pós-Graduação em Ciência e Tecnologia de Alimentos, DCTA/FAEM/UFPEL, Pelotas, RS, Brasil.E-mail: vamgler@hotmail.com; cmromano@bol.com.br; gabiha.alves@gmail.com; paraginskiricardo@yahoo.com.br Author for correspondence 


\section{Introduction}

The common bean (Phaseolus vulgaris L.), a dicotyledonous species of the Fabaceae family, is an important source of essential nutrients such as protein, iron, calcium, vitamins (especially B complex), carbohydrates and fiber. This is highly relevant for people in developing and developed countries. Brazil is the world's largest producer of the common bean, followed by India. Beans are present in the daily diet of Brazilians (LIN et al., 2008; RUPOLLO et al., 2011).

After harvest, beans undergo a series of processes such as pre-cleaning, drying, cleaning and storage prior to industrialization. The drying and storage conditions define the product's final physical and chemical qualities, which are directly perceived by the consumers. This is particularly true for hard beans, known as hard-to-cook beans (HTC), caused by the complexation of phenolic compounds with proteins and the structural change of starch, among other factors (MOHAN et al., 2011; NITHYA et al., 2011; RUPOLLO et al., 2011.).

Bean grains contain several phenolic compounds, particularly tannins, polymeric flavonoids that make up a large and diverse range of phenolic compounds produced by plants as secondary metabolites (CAMPOS-VEGA et al., 2010). The study of the behavior of these compounds during the storage of beans is of great importance due to their ability to complex and precipitate proteins from aqueous solutions. These are important parameters that affect the assessment of solubility, color, flavor, mineral bioavailability, and the in vitro digestibility of phaseolin in their native and denatured forms. They are capable of forming complexes, primarily through hydrophobic interactions (NASARABBAS et al., 2009; NJOROGE et al., 2014).

Polyphenyloxidase and peroxidades enzymes are widely distributed in nature and play important roles in numerous metabolic processes. They are responsible for the various browning reactions in fruits, grains and vegetables, and are paramount in the degradation of phenolic compounds in the presence of oxygen (WALISZEWSKI et al., 2009).

Polyphenol oxidases catalyze two types of reactions involving oxygen. The first reaction involves the hydroxylation of monophenols to form ortho-diphenols, and the second reaction involves the oxidation of ortho-diphenols to form ortho-quinone (WALISZEWSKI et al., 2009). The darkening of bean tegument in the presence of oxygen is due to the enzymatic oxidation of phenolic compounds by polyphenol oxidase. In this context, Acosta-Estrada et al. (2014) emphasize that the concentration of tannins in the seed coat of colored beans are high when compared to those in light-colored beans.

Several studies have been conducted to evaluate the effect of storage on the quality parameters of beans. This includes loss of mass, qualitative and quantitative protein losses, changes in acidity, and others. Moreover, changes in the grains during storage due to the dry conditions and its effect on the quality parameters and nutritional value still need to be studied. Taking the above factors and the quality parameters of beans for consumption and as raw materials for the food industry into consideration, the current study analyzes the effect of the drying temperature on the quality of black beans stored in a conventional system for 225 days.

\section{Material and Methods}

Materials and the drying and storage conditions of beans

Black beans, cv. Guapo, produced in Canguçu RS Brazil, were used. Grains were harvested at $18 \%$ moisture and dried in a stationary dryer pilot model LABGRÃOS - UFPEL, consisting of a perforated central cylinder and axial air distribution with a $0.90 \mathrm{~m}$ diameter and $1.00 \mathrm{~m}$ height, and an operating capacity of $120 \mathrm{~kg}$. The drying air was heated up to 30,45 and $60{ }^{\circ} \mathrm{C}$ by passing it through electrical resistances and inflated with the plenum of the dryer air flow $2 \mathrm{~m}^{3} \mathrm{~min} \mathrm{~m}^{-2}$ perforated 
plate. These temperatures were chosen because they are commonly used by bean industrialization companies. The drying time at temperatures of 30 , 45 and $60{ }^{\circ} \mathrm{C}$ was 32,20 and $14 \mathrm{~h}$, respectively. From each dried 50-kg-sample, aliquots of $5 \mathrm{~kg}$ were retrieved, placed in woven polypropylene bags and stored in the conventional system. The grains were stored for 225 days in the dark and monitored by an environmental condition control, with forced aeration when the temperature exceeded $20{ }^{\circ} \mathrm{C}$ and purged with aluminum phosphate whenever an insect attack was detected. The psychrometric air conditions in the storage environment were monitored weekly with wet-bulb temperature and dry-bulb temperature psychrometers. Sampling and analysis was performed at the time of storage (initial time), and at 75, 150 and 225 days.

\section{Moisture content}

The beans' moisture content during the storage period was determined by drying in an oven at $105 \pm 3{ }^{\circ} \mathrm{C}$ for $24 \mathrm{~h}$, with natural air circulation, according to the recommendations by the American Society of Agricultural Engineers (ASAE, 2000).

\section{Integrity and roughness}

The identification and quantification of the beans physical integrity and roughness was performed according to the procedures and standards for the qualification and commercialization of beans regulated by the Ministério da Agricultura, Pecuária e Abastecimento (MAPA), according to Decree no. 12 of the $28^{\text {th }}$ March 2008 (BRASIL, 2008). The results are expressed in percentage of broken grains and roughness.

\section{Cooking time}

The cooking time of the grains stored under each set of conditions was determined at day 1 (initial), 75, 150 and 225 by Burr et al. (1968) and further modifications. Prior to cooking, grain samples (25 beans) were soaked in $80 \mathrm{ml}$ of deionized water for $12 \mathrm{~h}$. A Mattson-modified cooker was used to determine the cooking time of each bean. The cooker comprised 25 stainless steel cylindrical holes, with 82-g piercing tip rods in contact with the surface of the bean. The cooker was then placed into a $2 \mathrm{~L}$ beaker containing $400 \mathrm{ml}$ of boiling water. The beans were considered cooked when the 2-mm diameter piercing tip of the brass rods penetrated the beans. The cooking time was the time required for $50 \%$ of the grains to be cooked, indicated by the plungers penetrating each bean.

\section{Protein content and soluble protein}

The nitrogen content was determined according to AOAC (2006), whilst the protein content was measured using the conversion factor of nitrogen to protein of 6.25. The soluble protein content was evaluated following Bradford's method (BRADFORD, 1976). The extract was obtained by mixing $0.25 \mathrm{~g}$ of raw, dry beans, which were ground to a particle size of 70-mesh, with $20 \mathrm{ml}$ of a 50 mol..$^{-1}$ buffer solution of potassium hypophosphate at $\mathrm{pH} 6.8$, and centrifuged at $4000 \mathrm{rpm}$ for $10 \mathrm{~min}$. After $0.1 \mathrm{ml}$ of the extract was placed quickly into a test tube, $5 \mathrm{ml}$ of Coomassie Blue was added. The tube was shaken with a vortex mixer and care was taken to avoid the formation of a foam. After $10 \mathrm{~min}$, a reading was recorded using a spectrophotometer at $595 \mathrm{~nm}$. The standard curve was prepared using a $1 \mathrm{mg} \mathrm{ml} \mathrm{m}^{-1}$ Bovine Serum Albumin (BSA) solution in a $50 \mathrm{~mol}^{-1}$ hypophosphate potassium buffer at $\mathrm{pH}$ 6.8. Dilutions of 20, 40, 60 and $80 \mathrm{mg} \mathrm{ml}^{-1}$ were added to a solution of potassium hypophosphate for the preparation of a standard curve. The soluble protein was expressed in $\mathrm{mg} \mathrm{g}^{-1}$ per sample.

\section{Fat content and fat acidity}

The fat content was determined using the method from the Association of Official Analytical Chemists 
(AOAC, 2006). The fat acidity was determined following the titrimetric procedure described by AOCS (2011). The titratable acidity was expressed in mg of potassium hydroxide required to neutralize the acids in $1 \mathrm{~g}$ of sample using phenolphthalein solution as an indicator.

\section{Tannins}

The method proposed by Deshpande et al. (1986) was used to determine the tannin content. 0.5 g samples of raw, dried, and ground beans with a 70-mesh particle size mixed with $20 \mathrm{ml}$ of methanol under constant agitation for $20 \mathrm{~min}$ were used for extraction. The sample was filtered through glass wool and $2 \mathrm{ml}$ of the filtrate was collected; $2.5 \mathrm{ml}$ of $\mathrm{HCl}$ was added to methanol $8 \%$. $2.5 \mathrm{ml}$ of $1 \%$ vanillin was added to the methanol. Likewise, $25 \mathrm{ml}$ of methanol and $2.5 \mathrm{ml}$ of vanillin $1 \%$ were added to the methanol for a reagent blank. The absorbance was measured at $500 \mathrm{~nm}$ using a spectrophotometer after $20 \mathrm{~min}$ at $30{ }^{\circ} \mathrm{C}$. The standard curve was prepared with catechin (Sigma Chemicals), $1 \mathrm{mg}$ $\mathrm{ml}^{-1}$ in methanol. Dilutions of $0,1,2,5,10 \mathrm{mg} \mathrm{ml}^{-1}$ methanol solution were used to prepare the standard curve. Based on the standard curve, the tannin content was calculated to be approximately $42 \%$ of the catechin equivalent.

\section{Peroxidase}

The enzyme activity of peroxidase was determined according to a modified technique described by Matsuno and Uritani (1972). The enzyme was extracted by homogenizing $0.5 \mathrm{~g}$ of ground beans for $3 \mathrm{~min}$ at $4{ }^{\circ} \mathrm{C}$ in $15 \mathrm{ml}$ of a 0.1 mol $1^{-1}$ phosphate buffer solution at $\mathrm{pH} 6.0$, before the mixture was centrifuged at $5000 \mathrm{rpm}$ for 20 $\mathrm{min}$ and then filtered. One $\mathrm{ml}$ of enzyme extract was incubated with $0.4 \mathrm{ml}$ of hydrogen peroxide at $3 \%, 2.0 \mathrm{ml}$ of a $0.1 \mathrm{~mol} \mathrm{l}^{-1}$ buffer at $\mathrm{pH} 5.0$, and 4.0 $\mathrm{mL}$ of guaiacol $0.5 \%$. An absorbance reading was performed immediately using a spectrophotometer at $470 \mathrm{~nm}$. One enzyme unit is defined as the amount of enzyme that caused an increase of 0.001 absorbance units per minute of reaction. The peroxidase enzyme activity was expressed in units per gram of beans per minute.

\section{Polyphenoloxidase}

The procedure used to obtain the enzymatic extract was the same as for the peroxidase, and carried out according to a modified method reported by Hyodo and Yang (1971). $2.79 \mathrm{ml}$ of an $80 \mathrm{mM}$ catechol solution prepared in a $0.1 \mathrm{~mol} \mathrm{1}^{-1}$ sodium phosphate buffer at $\mathrm{pH} 7.2$ was added to the 0.21 $\mathrm{ml}$ of enzyme extract collected. For the reagent blank, $2.79 \mathrm{ml}$ of the catechol solution prepared in a $0.1 \mathrm{~mol} \mathrm{l}^{-1}$ sodium phosphate buffer at $\mathrm{pH} 7.2$ was added. An absorbance reading was performed after 2 min using a spectrophotometer at $420 \mathrm{~nm}$. One enzyme unit is defined as the amount of enzyme that caused an increase of 0.001 absorbance units per minute of reaction. The enzyme polyphenol oxidase activity was expressed in units per gram of beans per minute.

\section{Statistical analysis}

All measurements were performed in triplicate and reported as an average with a standard deviation. Tukey's test was used to compare the mean values at a $5 \%$ level of significance, with analysis of variance (ANOVA).

\section{Results and Discussion}

\section{Moisture content}

Table 1 shows that the moisture varied according to the storage time, following a trend towards equilibrium at the conditions in which the grains were stored. A similar behavior was observed for all grains regardless of the drying temperature used. The moisture content increased from $11.5 \%$ to approximately $14 \%$ after storage for 225 days. The 
increased grain moisture with storage time occurs because the conventional system allows exchange between the grain and air in the storage environment. When the surrounding relative air humidity of the storage environment is higher than the equilibrium humidity, water in the air is transferred to the grains. The humidity in the grain increases to achieve a hygroscopic balance. The proteins and starch are the main causes of this type of absorption.
From storing beans under five different moisture conditions (12, 14, 16, 18 and $20 \%)$ and four different temperature conditions $(10,20,30$ and 40 ${ }^{\circ} \mathrm{C}$ ), Rani et al. (2013) observed that the moisture content remained constant during 16 weeks of storage due to the control of the storage relative humidity established according to each treatment.

Table 1. Grain moisture of air-dried beans stored for 225 days in a conventional system at three temperatures.

\begin{tabular}{ccccc}
\hline \multirow{2}{*}{ Treatment } & \multicolumn{4}{c}{ Storage period (days) } \\
\cline { 2 - 5 } & 1 & 75 & 150 & 225 \\
\hline $30{ }^{\circ} \mathrm{C}$ & $\mathrm{A} 11.5 \pm 0.25 \mathrm{~b}$ & $\mathrm{~A} 11.95 \pm 0.21 \mathrm{~b}$ & $\mathrm{~A} 13.96 \pm 0.50 \mathrm{a}$ & $\mathrm{A} 14.16 \pm 0.58 \mathrm{a}$ \\
$45^{\circ} \mathrm{C}$ & $\mathrm{A} 11.6 \pm 0.43 \mathrm{~b}$ & $\mathrm{~A} 12.30 \pm 0.30 \mathrm{~b}$ & $\mathrm{~A} 14.06 \pm 0.40 \mathrm{a}$ & $\mathrm{A} 14.40 \pm 0.50 \mathrm{a}$ \\
$60^{\circ} \mathrm{C}$ & $\mathrm{A} 11.5 \pm 0.30 \mathrm{c}$ & $\mathrm{A} 12.40 \pm 0.30 \mathrm{~b}$ & $\mathrm{~A} 13.75 \pm 0.35 \mathrm{a}$ & $\mathrm{A} 13.90 \pm 0.30 \mathrm{a}$ \\
\hline
\end{tabular}

${ }^{\text {a }}$ Simple arithmetic averages of three replicates followed by the same capital letters in the same column, and the lowercase letter equals the line for the same parameter, which do not differ by the Tukey test $(\mathrm{p} \leq 0.05)$.

\section{Physical integrity}

Figure 1a demonstrates that physical integrity, represented by the appearance of broken grain defects and roughness, is greater in beans dried at higher temperatures, especially at a temperature of $60{ }^{\circ} \mathrm{C}$. Because this amount does not change during storage, it may be said that the integrity is more dependent than the defects resulting from the conditions of storage.

The increase in broken grains is the result of stress to which the peripheral layers of the grains are subjected because higher temperatures and moisture contents provide higher rates of drying in the outer layers of the product at the start of the drying process. Thus, there is an imbalance of energy (heat) and mass (water) between the peripheral and the innermost layers of the grains during the drying process. They act on the cell structure and consequently cause changes (RADAJEWSKI et al., 1992).
As for surface roughness (Figure 1b), only a temperature of $60^{\circ} \mathrm{C}$ affected the bean grains, with no observable change at 30 or $45^{\circ} \mathrm{C}$. Air drying at higher temperatures caused a greater initial imbalance in the distribution of water molecules and heat between the various layers of the grains. As the beans are rich in protein (approximately $21 \%$ ) and are more hygroscopic than the other molecules present, the protein part of the cotyledons is the first to undergo a change in water content during the drying process. Thus, a large volume decrease occurs due to dehydration in the cotyledons. This contrasts to the behavior of the tegument, with a mineral and fiber content characterized by a low hygroscopy, which are augmented. Wrinkling ensues, as studies by Radajewski et al. (1992) have demonstrated. 
Figure 1. The broken grains (A) and roughness (B) of beans air-dried at three temperatures and stored for 225 days in a conventional system.

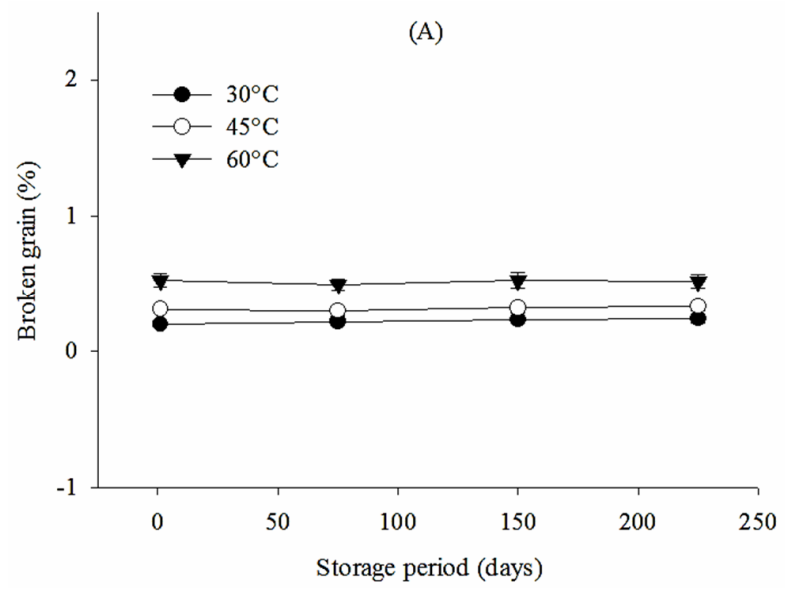

\section{Cooking time}

An increase in the storage time caused an increase in the cooking time (Figure 2), as indicated from the three drying temperatures evaluated. From a cooking time of $21 \mathrm{~min}$ at the beginning of storage, the cooking time increased to 35,36 and 39 min for

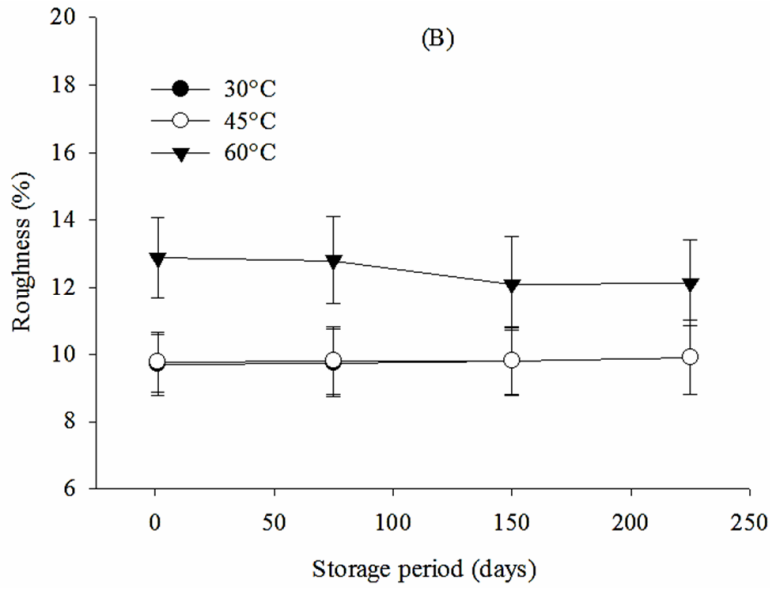

beans air-dried for 225 days at 30,45 and $60{ }^{\circ} \mathrm{C}$, respectively; major changes were observed when grains were dried at $60{ }^{\circ} \mathrm{C}$. These results are similar to those reported by Nasar-Abbas et al. (2008). They observed that the cooking time of black beans increased with storage under various conditions.

Figure 2. The cooking time ( $\mathrm{min}$ ) of beans air-dried at three temperatures and stored for 225 days in a conventional system.

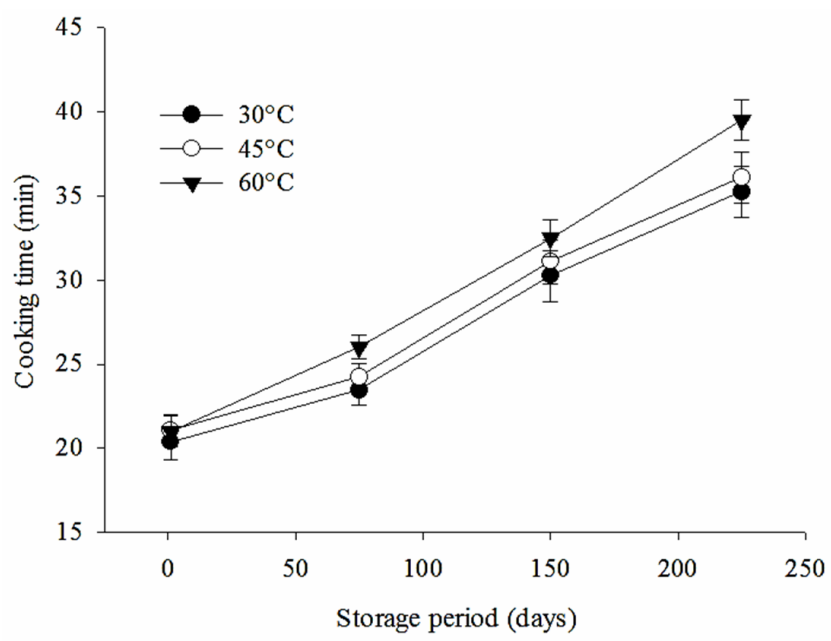


In his research on the storage conditions of Carioca beans over two years using the same method to determine the cooking time, Shiga et al. (2004) showed that there was a significant increase in the cooking time over the storage time investigated. Grain hardening increases with storage time and is related to changes in the cell walls of the bean cotyledons (RUPOLLO et al., 2011). The cell wall components such as polysaccharides, glycoproteins and phenolic compounds may undergo crosslinking with each other, making the wall more rigid and resistant to boiling (DÍAZ et al., 2010).

\section{Crude protein and protein solubility}

There was a slight decline in the crude protein content during the storage period (Figure 3a) from 21.3 to $20.1 \%$ at the three temperatures evaluated. In fact, no difference was observed between them, in agreement with the results reported by Siddiq et al. (2010) and Rani et al. (2013). The behavior of this important protein component of beans may be explained by the degradation of the proteins into small peptides and amino acids as a result of the metabolic needs of the grains and associated bodies, and is correlated with the increased grain moisture during the storage period (Table 1). The structure of the globulins changes during the protein degradation, exposing hydrophobic groups, which in the native state of the proteins are oriented towards the interior of the structure. As the protein solubility is dependent on its ability to form hydrogen bonds, there are less active sites available for binding with water, and the solubility is lowered (Figure 3b). Rani et al. (2013) reported a similar behavior working with stored beans. The increased water content of the grains, which resulted from a hygroscopic equilibrium, explains the proportional reduction of the protein content.

The primary importance of protein solubility is the fact that it influences other functional properties such as gelation, emulsification and foaming during cooking. These characteristics influence the consistency of the broth during food preparation, an important characteristic in the product's acceptability.

The raw beans protein solubility significantly decreased over the storage time (Figure 3b). In fact, a gradual decrease in the protein solubility was observed for all samples tested from 72 to $38 \mathrm{mg} \mathrm{g}^{-1}$ after storage for 225 days regardless of the drying temperature used. Paraginski et al. (2014) reported a $47 \%$ reduction in the protein solubility during the storage of maize at a humidity of $14 \%$ and a temperature of $35^{\circ} \mathrm{C}$ after 12 months.

Figure 3. The crude (A) and soluble protein (B) content of beans air-dried at three temperatures and stored for 225 days in a conventional system.
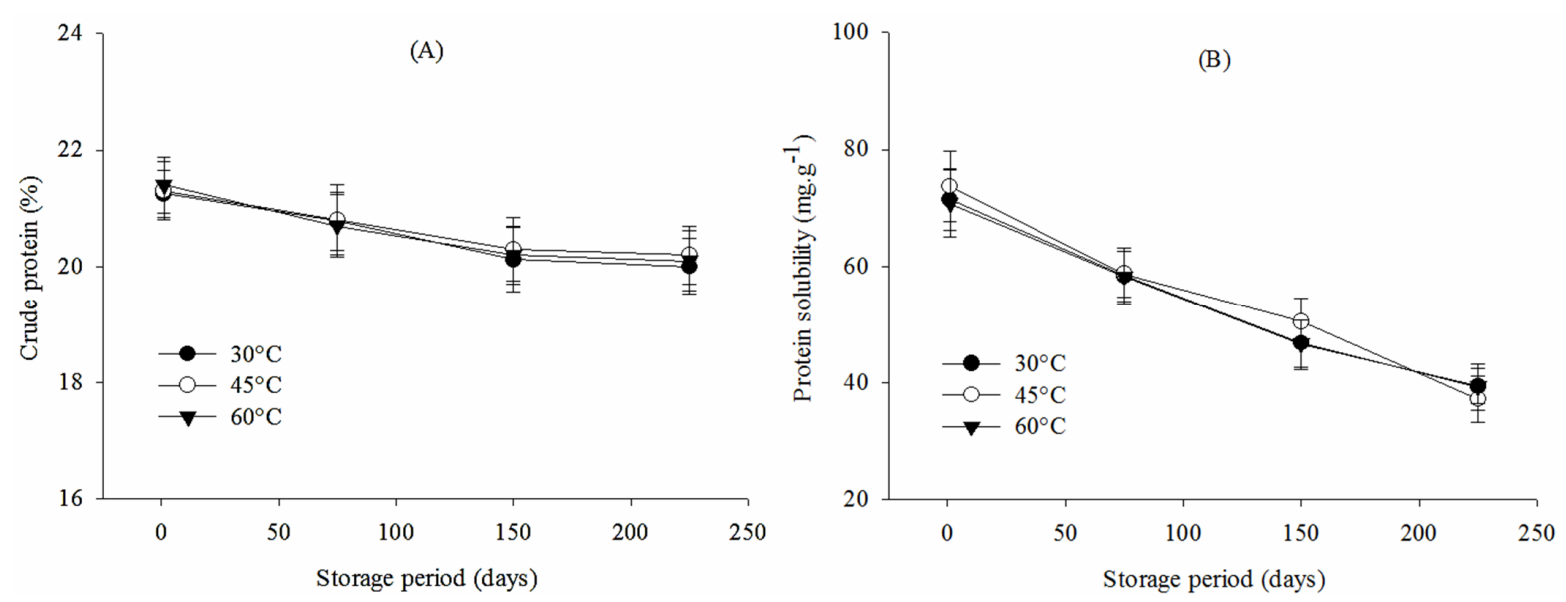
Similarly, studies by Liu et al. (2008) demonstrated that the protein solubility of soybeans decreased significantly after one year of storage under adverse conditions (88\% relative humidity and $30{ }^{\circ} \mathrm{C}$ ). Changes in these characteristics were due to molecular changes in the B-pleated structure and disulfide bonds, with protein denaturation, in addition to the possible complexation of proteins with phenolic acids during storage (CHEN et al., 2011; STANOJEVIC et al., 2011).

\section{Fat content and fat acidity}

There was a reduction in the lipid content during storage (Figure 4a), and an increase in the fat acidity (Figure $4 \mathrm{~b}$ ) after 75 days of storage. A gradual increase at 150 and 225 days was observed regardless of the temperature used in grain drying.
The increased acidity is indicative of an increase in free fatty acids resulting from triglycerides and phospholipid molecules. The fatty acids are produced from the action of phospholipases and lipases, which are enzymes that are present in the beans or produced by associated microflora. These enzymes break the ester bonds in triglycerides, while lipoxygenase causes the oxidation of unsaturated fatty acids in the carbon chain. This explains the small reduction in the lipid content of the grains during storage (Figure 4a). Naz et al. (2004) also reported this phenomenon in vegetable oil storage.

Toci et al. (2013) also observed a reduction in the level of triglycerides after six months while studying the storage of coffee at $30{ }^{\circ} \mathrm{C}$. This was attributed to the action of hydrolytic enzymes. Rani et al. (2013) reported an increased acidity in beans stored under various conditions.

Figure 4. The lipid content (A) and fat acidity (B) of beans air-dried at three temperatures and stored for 225 days in a conventional system.

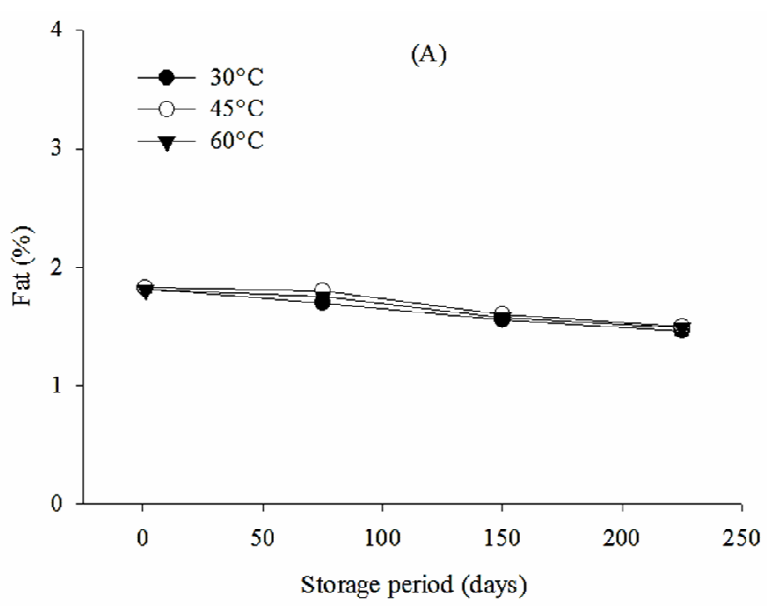

\section{Tannins}

The results shown in Table 2 indicate that the grain tannin levels remained stable up to 75 days of storage. Significant reductions occurred only after 150 and 225 days, with a $42 \%$ variation at the end of storage. It must be understood that the tannin

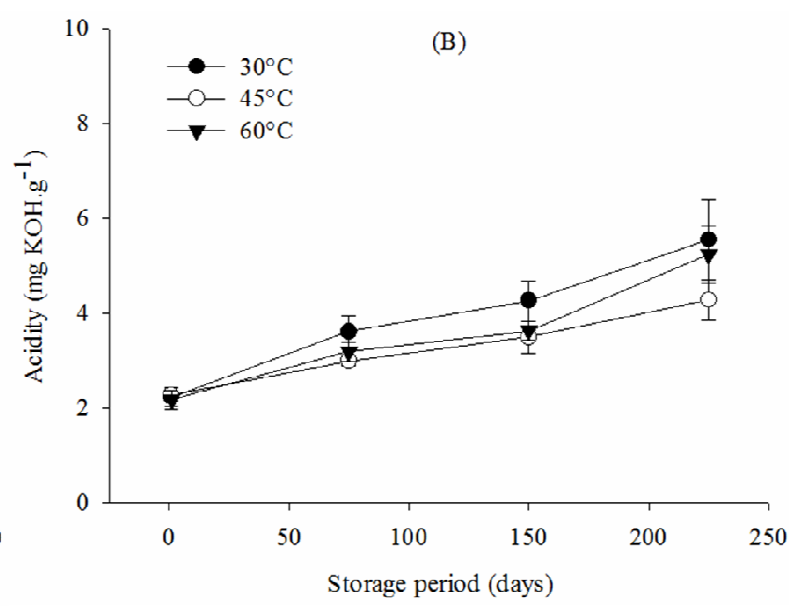

content is not influenced by the temperature of the air. Oomah et al. (2010) reported that the color of the integument, total phenolic compounds, tannin and anthocyanin contents varied according to the location and management of cultivation. 
Table 2. Tannin content $\left(\mathrm{mg} \mathrm{g}^{-1}\right)$ of beans air-dried at three temperatures and stored for 225 days in a conventional system.

\begin{tabular}{ccccc}
\hline \multirow{2}{*}{ Treatment } & \multicolumn{4}{c}{ Storage period (days) ${ }^{\mathrm{a}}$} \\
\cline { 2 - 5 } & 1 & 75 & 150 & 225 \\
\hline $30^{\circ} \mathrm{C}$ & $\mathrm{A} 48.95 \pm 2.00 \mathrm{a}$ & $\mathrm{A} 50.37 \pm 2.30 \mathrm{a}$ & $\mathrm{A} 33.37 \pm 4.50 \mathrm{~b}$ & $\mathrm{~A} 25.73 \pm 2.00 \mathrm{c}$ \\
$45^{\circ} \mathrm{C}$ & $\mathrm{A} 50.14 \pm 4.70 \mathrm{a}$ & $\mathrm{A} 56.39 \pm 6.60 \mathrm{a}$ & $\mathrm{A} 44.39 \pm 7.20 \mathrm{a}$ & $\mathrm{A} 29.29 \pm 3.00 \mathrm{~b}$ \\
$60^{\circ} \mathrm{C}$ & $\mathrm{A} 46.36 \pm 2.90 \mathrm{a}$ & A49.28 $\pm 3.00 \mathrm{a}$ & A31.53 $\pm 5.21 \mathrm{~b}$ & A28.72 $\pm 2.70 \mathrm{~b}$ \\
\hline
\end{tabular}

${ }^{a}$ Simple arithmetic averages of three replicates followed by the same capital letters in the same column, and the lowercase letter equals the line for the same parameter, which do not differ by the Tukey test ( $\mathrm{p} \leq 0.05)$.

Studies by Ferreira et al. (2004) on the pigeon pea showed similar behavior, with a slight increase in the tannin content after 30 days of storage, and a significant reduction after 60 and 90 days. Such behavior is explained by the presence of high molecular weight tannins with hydroxyl groups that are capable of forming stable bonds with proteins (NASAR-ABBAS et al., 2008). Furthermore, tannins may migrate from the seed coat to the cotyledons, forming cross-links with cellular macromolecules within the cell walls or in the middle lamella during storage. Tannins may even undergo oxidation by enzymes, such as peroxidase and polyphenoloxidase (DÍAZ et al., 2010).

\section{Peroxidase and polyphenoloxidase}

The peroxidase activity results that are shown in Figure 5a indicate a small difference at the end of drying between temperatures $\left(30,45\right.$ and $\left.60^{\circ} \mathrm{C}\right)$. In the case of the polyphenoloxidase activity (Figure $5 b)$, the behavior was similar for all treatment methods over the entire treatment period of 225 days. However, when the drying temperature was increased from 30 to $60{ }^{\circ} \mathrm{C}$, the activity increased earlier in storage; it is likely the drying temperature was within the ideal range for activity of the enzyme. The activity was $52.74,78.85$ and $88.66 \mathrm{Ug}^{-1}$ at a temperature of 30,45 and $60^{\circ} \mathrm{C}$, respectively.

Figure 5. The activity of peroxidase (A) and polyphenoloxidase (B) of beans air-dried at three temperatures and stored for 225 days in a conventional system.

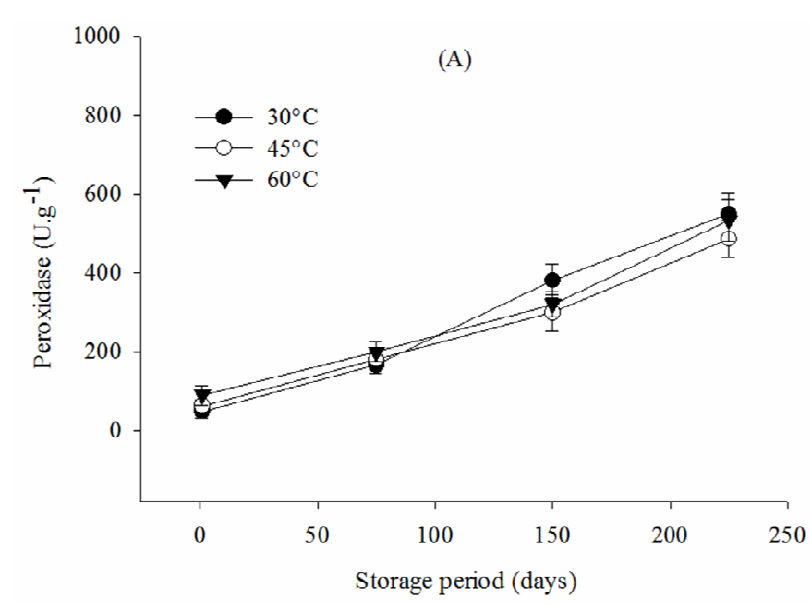

The activity of peroxidase and polyphenoloxidase during storage increased every day (Figures $5 \mathrm{a}$ and $5 b)$, with a more intense increase of peroxidase. This observed behavior is not a consequence of the

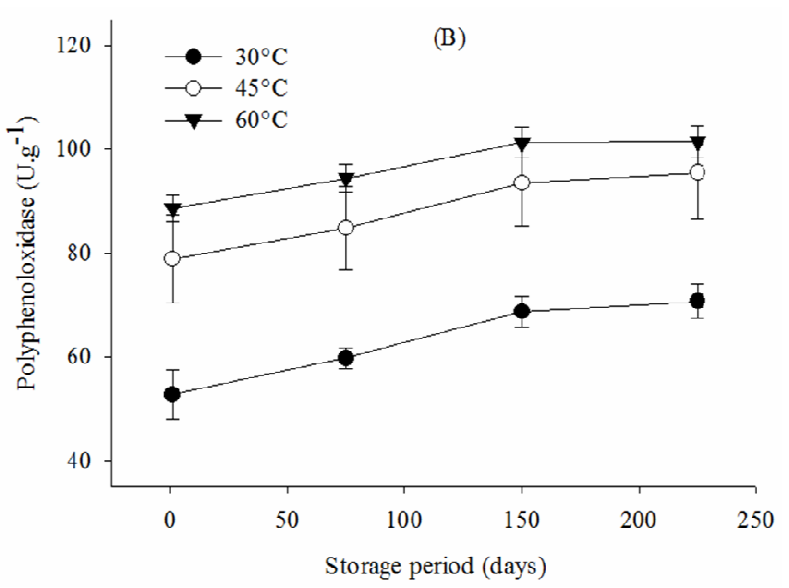

drying temperature. This increase may be explained by the increase in the grain moisture (Table 1) and subsequent increase in the enzymatic activity. This causes the cellular structure of the grains to change, 
which may be associated with the observed increase in the cooking time of the grains (Figure 2). These enzymes play an important role in the color quality and commercial properties of the bean due their intragranular functions (HAVKIN-FRENKEL et al., 2005).

\section{Conclusions}

An increase in storage time leads to changes in the chemical composition of beans subjected to artificial air drying at temperatures between 30 and $60{ }^{\circ} \mathrm{C}$. The increase in broken grains and roughness is temperature-dependent, and the drying air temperature of $60{ }^{\circ} \mathrm{C}$ causes a more significant increase when compared to temperatures of 30 and $45{ }^{\circ} \mathrm{C}$. The same behavior was observed for the cooking time where the greatest increase at the end of 225 days of storage was reported in beans dried at $60{ }^{\circ} \mathrm{C}$.

An increased storage time caused a decrease in the protein solubility and crude protein, tannin and lipid content. The cooking time, fat acidity and peroxidase and polyphenoloxidase activity increased regardless of the drying temperature. Therefore, these parameters are important in the quality control of beans for consumption and as a raw material for the food industry because they directly affect the consumer acceptability and the product quality.

\section{Acknowledgements}

We would like to thank CAPES (Coordenação de Aperfeiçoamento de Pessoal de Nível Superior), CNPq (Conselho Nacional de Desenvolvimento Científico e Tecnológico), SCT-RS (Secretaria da Ciência e Tecnologia do Estado do Rio Grande do Sul), FAPERGS (Fundação de Amparo à Pesquisa do Estado do Rio Grande do Sul.) and Polo de Inovação Tecnológica em Alimentos da Região Sul.

\section{References}

ACOSTA-ESTRADA, B. A.; GUTIÉRREZ-URIBE, J. A.; SERNA-SALDÍVAR, S. O. Bound phenolics in foods, a review. Food Chemistry, Washington, v. 152, n. 1, p. 46-55, 2014.

AMERICAN OIL CHEMISTS SOCIETY - AOCS. Official Methods and recommended practices of the AOCS. $6^{\text {th }}$ ed. Champaign: AOCS International, 2011.

AMERICAN SOCIETY OF AGRICULTURAL ENGINEERS - ASAE. Moisture measurement-unground grain and seeds. Standards. St. Joseph: ASAE, 2000. 563 p.

ASSOCIATION OF OFFICIAL ANALYTICAL CHEMISTS - AOAC. Official methods of analysis. $18^{\text {th }}$ ed. Washington D.C.: AOAC International, 2006.

BRADFORD, M. M. A rapid and sensitive method for the quantitation of microgram quantities of protein utilizing the principle of protein-dye binding. Analytical Biochemistry, Philadelphia, v. 72, n. 1, p. 248-254, 1976.

BRASIL. Ministério da Agricultura, Pecuária e Abastecimento. Instrução Normativa $\mathrm{n}^{\circ} 12$, de 28 de março de 2008. Regulamento técnico do feijão. Diário Oficial [da] União, Brasília, 31 mar. 2008, Seção 61, p. $1-18$.

BURR, H. K.; KON, S.; MORRIS, H. J. Cooking rates of dry beans as influenced by moisture content and temperature and time of storage. Food Technology, Chicago, v. 22, n. 1, p. 336-338, 1968.

CAMPOS-VEGA, R.; LOARCA-PIÑA, G.; OOMAH, B. D. Minor components of pulses and their potential impact on human health. Food Research International, Barking, v. 43, n. 2, p. 461-482, 2010.

CHEN, L.; CHEN, J.; REN, J.; ZHAO, M. Effects of ultrasound pretreatment on the enzymatic hydrolysis of soy protein isolates and on the emulsifying properties of hydrolysates. Journal of Agricultural and Food Chemistry, Washington, v. 59, n. 6, p. 2600-2609, 2011.

DESHPANDE, S. S.; CHERYAN, M.; SALUNKE, D. K.; LUH, B. S. Tannin analysis of food products. Critical Reviews in Food Science and Nutrition, Amherst, v. 24, n. 4, p. 401-449, 1986.

DÍAZ, A. M.; CALDAS, G. V.; BLAIR, M. W. Concentrations of condensed tannins and anthocyanins in common bean seed coats. Food Research International, Barking, v. 43, n. 2, p. 595-601, 2010.

FERREIRA, E. C.; NOGUEIRA, A. R. A.; SOUZA, G. B.; BATISTA, L. A. R. Effect of drying method and length of storage on tannin and total phenol concentrations in Pigeon pea seeds. Food Chemistry, Washington, v. 86, n. 1, p. 17-23, 2004. 
HAVKIN-FRENKEL, D.; FRENCH, J.; PAK, F.; FRENKEL, C. Inside vanilla: Vanilla planifolia's botany, curing options and future market prospect. Perfumer and Flavorist, Carol Stream, v. 30, n. 1, p. 30-35, 2005.

HYODO, H.; YANG, S. F. Ethylene-enhanced synthesis of phenylalanine ammonia-lyase in pea seedlings. Plant Physiology, Glasgow, v. 47, n. 1, p. 765-770, 1971.

LIN, L.; HARNLY, J. M.; PASTOR-CORRALES, M. S.; LUTHRIA, D. L. The polyphenolic profiles of common bean (Phaseolus vulgaris L.). Food Chemistry, Washington, v. 107, n. 1, p. 399-410, 2008.

LIU, C.; WANG, X.; MA, H.; ZHANG, Z.; GAO, W.; XIAO, L. Functional properties of protein isolates from soybeans stored under various conditions. Food Chemistry, Washington, v. 111, n. 1, p. 29-37, 2008.

MATSUNO, H.; URITANI, I. Physiological behavior of peroxidase isozymes in sweet potato root tissue injured by cutting or with black rot. Plant and Cell Physiology, Oxford, v. 13, n. 6, p. 1091-1101, 1972.

MOHAN, R. J.; SANGEETHA, A.; NARASIMHA, H. V.; TIWARI, B. K. Post-harvest technology of pulses. In: TIWARI, B. K.; GOWEN, A.; MCKENNA, B. (Ed.). Pulse foods: processing, quality and technological applications. São José: 2011. p. 171-192.

NASAR-ABBAS, S. M.; PLUMMER, J. A.; SIDDIQUE, K. H. M.; WHITE, P.; HARRIS, D.; DODS, K. Cooking quality of faba bean after storage at high temperature and the role of lignins and other phenolics in bean hardening. LWT - Food Science and Technology, Georgia, v. 41, n. 7, p. 1260-1267, 2008.

NASAR-ABBAS， S. M.; SIDDIQUE, K. H. M.; PLUMMER, J. A.; WHITE, P. F.; HARRIS, D.; DODS, K.; D’ANTUONO, M. Faba bean (Vicia faba L.) seeds darken rapidly and phenolic content falls when stored at higher temperature, moisture and light intensity. $L W T-$ Food Science and Technology, Georgia, v. 42, n. 10, p. 1703-1711, 2009.

NAZ, S.; SHEIKH, H.; SIDDIQI, R.; SAYEED, S. A. Oxidative stability of olive, corn and soybean oil under different conditions. Food Chemistry, Washington, v. 88, n. 2, p. 253-259, 2004.

NITHYA, U.; CHELLADURAI, V.; JAYAS, D. S.; WHITE, N. D. G. Safe storage guidelines for durum wheat. Journal of Stored Products Research, Manhattan, v. 47, n. 4, p. 328-333, 2011.

NJOROGE, D. M.; KINYANJUI, P. K.; MAKOKHA, A. O.; CHRISTIAENS, S.; SHPIGELMAN, A.; SILA, D. N.; HENDRICKX, M. E. Extraction and characterization of pectic polysaccharides from easy- and hard-to-cook common beans (Phaseolus vulgaris). Food Research International, Barking, v. 64, n. 1, p. 314-322, 2014.
OOMAH, B. D.; CORBÉ, A.; BALASUBRAMANIAN, P. Antioxidant and anti-inflammatory activities of bean (Phaseolus vulgaris L.) hulls. Journal of Agriculture and Food Chemistry, Washington, v. 58, n. 1, p. 8225-8230, 2010 .

PARAGINSKI, R. T.; VANIER, N. L.; BERRIOS, J. J.; OLIVEIRA, M.; ELIAS, M. C. Physicochemical and pasting properties of maize as affected by storage temperature. Journal of Stored Products Research, Manhattan, v. 59, n. 1, p. 209-214, 2014.

RADAJEWSKI, W.; JENSEN, T.; ABAWI, G. Y.; MCGAHAN, E. J. Drying rate and damage to navy beans. Transsactions of the ASAE, St. Joseph, v. 35, n. 2, p. 583-590, 1992.

RANI, P. R.; CHELLADURAI, V.; JAYAS, D. S.; WHITE, N. D. G.; KAVITHA-ABIRAMI, C. V. Storage studies on pinto beans under different moisture contents and temperature regimes. Journal of Stored Products Research, Manhattan, v. 52, n. 1, p. 78-85, 2013.

RUPOLLO, G.; VANIER, N. L.; ZAVAREZE, E. R.; OLIVEIRA, M.; PEREIRA, J. M.; PARAGINSKI, R. T.; DIAS, A. R. G.; ELIAS, M. C. Pasting, morphological, thermal and crystallinity properties of starch isolated from beans stored under different atmospheric conditions. Carbohydrate Polymers, Aveiro, v. 86, n. 3, p. 14031409, 2011.

SHIGA, T. M.; LAJOLO, F. M.; FILISETTI, T. M. C. Changes in the cell wall polysaccharides during storage and hardening of beans. Food Chemistry, Washington, v. 84, n. 1, p. 53-64, 2004.

SIDDIQ, M.; RAVI, R.; HARTE, J. B.; DOLAN, K. D. Physical and functional characteristics of selected dry bean (Phaseolus vulgaris L.) flours. LWT-Food Science and Technology, Georgia, v. 43, n. 2, p. 232-237, 2010.

STANOJEVIC, S. P.; BARAC, M. B.; PESIC, M. B.; VUCELIC-RADOVIC, B. V. Assessment of soy genotype and processing method on quality of soybean tofu. Journal of Agricultural and Food Chemistry, Washington, v. 59, n. 1, p. 7368-7376, 2011.

TOCI, A. T.; FERREIRA NETO, V. J. M.; TORRES, A. G.; FARAH, A. Changes in triacylglycerols and free fatty acids composition during storage of roasted coffee. $L W T$ - Food Science and Technology, Georgia, v. 50, n. 2, p. 581-590, 2013.

WALISZEWSKI, K. N.; MÁRQUEZ, O.; PARDIO, V. T. Quantification and characterisation of polyphenol oxidase from vanilla bean. Food Chemistry, Washington, v. 117 , n. 2, p. 196-203, 2009. 
